\title{
EHMTI-0038. Does hypophysial-gonadal system influence formation of tension-type headache in women of reproductive age?
}

\author{
K Derevyanko \\ From 4th European Headache and Migraine Trust International Congress: EHMTIC 2014 \\ Copenhagen, Denmark. 18-21 September 2014
}

The obvious difference in pain prevalence related to gender is well known, but the underlying mechanisms are not clearly identified. Female sex steroids may play an important role in this difference.

\section{Objective}

Estimation of hypophysial-gonadal hormones level and psychoemotional status in women of reproductive age with tension-type headache

\section{Methods}

We have evaluated the content of hypophysial-gonadal hormones in blood serum in luteal and follicular phases. Diagnosis has been made using ICHD-II. Psychoemotional status has been assessed by the scale of Beck, Hamilton and Spilberg.

\section{Results}

1.At moderate personal and reactive anxiety and depression in women with chronic tension-type headache (CTTH) the increased cortisol in blood has been found.

2. In a follicular phase the women with CTTH had the increased luteinizing $(52.2 \pm 7.5 \mathrm{IU} / \mathrm{l})$ and FSH $(18.2 \pm$ $1.4 \mathrm{IU} / \mathrm{l})$, while in a luteal phase- progesterone was high $(89.7 \pm 3.6 \mathrm{nmol} / \mathrm{l})$. Estradiol $(274.3 \pm 25.3 \mathrm{pg} / \mathrm{ml})$, testosterone $(2.4 \pm 0.3 \mathrm{ng} / \mathrm{ml})$ and cortisol $(877.2 \pm 35.6 \mathrm{nmol} / \mathrm{l})$ were increased as in the luteal and follicular phases of the ovary cycle. Quantitatively, the hypothesis-ovary and hypothesis-adrenal cortex hormones in patients with episodic tension headache were within the normal range in both phases of the ovary cycle.

3. In women CTTH was accompanied by moderate reactive and personal anxiety and evident depression during the ovary cycle becoming more intensive. The women with episodic tension-type headache demonstrated low anxiety and absence of depression in follicle and luteinizing phases.

\section{Conclusion}

The obtained data allow us to trace the pathogenic correlation between CTTH and hormonal deviations

No conflict of interest.

Published: 18 September 2014

doi:10.1186/1129-2377-15-S1-F5

Cite this article as: Derevyanko: EHMTI-0038. Does hypophysial-gonadal system influence formation of tension-type headache in women of reproductive age? The Journal of Headache and Pain 2014 15(Suppl 1):F5.

Neurology, Clinic of Bashkir State Medical University, Ufa, Russia

Submit your manuscript to a SpringerOpen ${ }^{\bullet}$ journal and benefit from:

- Convenient online submission

- Rigorous peer review

- Immediate publication on acceptance

- Open access: articles freely available online

- High visibility within the field

- Retaining the copyright to your article

Submit your next manuscript at $>$ springeropen.com (c) 2014 Derevyanko; licensee Springer. This is an Open Access article distributed under the terms of the Creative Commons Attribution License (http://creativecommons.org/licenses/by/2.0), which permits unrestricted use, distribution, and reproduction in any medium, provided the original work is properly cited. 